\title{
Serum Interleukin Profile in Patients with Graves Orbithopathy
}

\author{
Réti Zsuzsánna, Kun IZ, Radu Pop Corina Cristina \\ University of Medicine and Pharmacy, Tîrgu Mureș, Romania
}

\begin{abstract}
Background: Graves' orbitopathy (GO) is considered an autoimmune condition in close relationship with Graves' disease (GD) affecting the thyroid. Several similarities exist between the two conditions, sharing the common antigen and the characteristics of the inflammation mediated by a number of cytokines. The result of the immune reactions will lead to the expansion of adipose tissue, production of glycosaminoglycans and soft tissue inflammation.

Material and methods: In our study we examined the serum level of interleukin-1 (IL-1), interleukin 2 (IL-2), interleukin-4 (IL-4), interleukin-6 (IL-6), interleukin-8 (IL-8), interleukin-10 (IL-10), monocyte chemoattractant protein-1 (MCP-1), tumor necrosis factor-alpha (TNF- $\alpha$ ), and interferon-gamma (IFN- $\gamma$ ) in correlation with the activity of disease and smoking habits in 25 patients with GD and GO.

Results: We found that smokers had higher serum IL-6 and lower serum MCP-1, IL-8 and TNF- $\alpha$ level compared to non-smokers. Also, we found a weak positive correlation between serum IL-10, IFN- $\gamma$ and disease activity (clinical activity score, CAS) and negative correlation between serum IL-1 and activity.

Conclusion: Our findings support the fact that some cytokines (IL-10, IFN- $\gamma, \mathrm{IL}-1)$ play a role in active disease, while others are influenced by environmental factors, such as smoking (IL-6, IL-8, TNF- $\alpha$ ). The discrepancy of cytokine profiles may reflect different patient characteristics, such as disease stage and disease activity and determination of serum cytokines would be useful in selecting patients who need more aggressive treatment protocols.
\end{abstract}

Keywords: Graves' Orbitopathy, interleukins, smoking, disease activity

Received: 29 January 2013

\section{Introduction}

Graves' orbitopathy (GO) is a condition frequently associated with Graves' disease (GD) (autoimmune thyroid disease, goiter and thyrotoxicosis). It can be clinically relevant in almost $70 \%$ of patients but with sensitive imaging techniques it can be demonstrated in over $90 \%$ of patients with GD [1]. The most common symptoms include lid retraction (almost invariably the upper lid being affected) [2], periorbital swelling and redness, conjunctival redness, lagophtalmos and proptosis [3]. The change in appearance can be very disturbing for patient but the true danger is represented by the most severe complications - corneal ulcerations and optic nerve ischemia leading in severe cases to sight loss [4].

The onset of GO varies in association with thyroid disease, it may be present from the beginning of hyperthyroidism, it can follow within months after the thyroid dysfunction, or, in some cases it can precede the thyrotoxicosis. A small percentage of GO patients develop GO without any evidence of thyroid disease, called euthyroid GO [5,6]. Clinical evaluation of GO is made upon signs and symptoms according to algorithms offered by the European Group on Graves' Orbitopathy (EUGOGO) [7,8,9,10]. This includes appreciation of severity by the NOSPECS stages and activity by the Clinical Activity Score (CAS) (Tables I and II).
The pathogenesis of GO is based upon the concept of the common antigen shared by the thyroid and orbit as well, presumably the thyroid stimulating hormone (TSH) receptor. Stimulating antibodies attached to the receptor generate a cascade of immune reactions and cytokine production leading to adipogenesis and expansion of the adipose tissue within the connective sheets in the orbit, inflammatory infiltration and production of glycosaminoglycans $[11,12]$.

The recruited inflammatory cells, $\mathrm{T}$ and B lymphocytes, macrophages, mast cells, orbital fibroblasts interact and promote local inflammation by signal molecules represented by cytokines: IL-1 (interleukin-1), IL-2, IL-4, IL6, IL-8, IL-10, IL-16, IL-18, IFN- $\gamma$ (interferon gamma), TNF- $\alpha$ (tumor necrosis factor alpha), TGF- $\beta$ (transforming growth factor beta), RANTES (Regulated on Activation, Normal T Cell Expressed and Secreted) and MCP-1 (monocyte chemoattractact protein). In recent-onset GO Th1 pattern dominates (IL- 2 , IFN- $\gamma$, TNF- $\alpha$ ), and in remitted, inactive disease the Th2 pattern cytokines (IL-4, IL-5, IL-10) represent the major cytokines $[13,14]$. The result of cytokine stimulation on the orbital fibroblast is the acceleration of acute immune reactions like expression of heat shock protein 72, production of prostaglandin E2, enhancement of glycosaminoglycan synthesis, adipocyte differentiation and adipogenesis $[15,16]$.

The most important environmental factor in close association with the progression of GO is smoking. Smok- 
Table I. Stages of severity - NOSPECS stages

\begin{tabular}{|c|c|c|c|}
\hline Class & Mnemonics & Grade & Change \\
\hline 0 & $\mathrm{~N}$ & & No signs or symptoms \\
\hline 1 & $\mathrm{O}$ & & Only signs \\
\hline \multirow[t]{5}{*}{2} & S & & $\begin{array}{l}\text { Soft tissue involvement with symptoms and } \\
\text { signs }\end{array}$ \\
\hline & & 0 & absent \\
\hline & & a & minimal \\
\hline & & $b$ & moderate \\
\hline & & c & marked \\
\hline \multirow[t]{5}{*}{3} & $P$ & & Proptosis \\
\hline & & 0 & $<23 \mathrm{~mm}$ \\
\hline & & a & 23-24 mm \\
\hline & & $b$ & $25-27 \mathrm{~mm}$ \\
\hline & & c & $\geq 28 \mathrm{~mm}$ \\
\hline \multirow[t]{5}{*}{4} & E & & Extraocular muscle involvement \\
\hline & & 0 & absent \\
\hline & & a & Limitation of motion in extremes of gaze \\
\hline & & $b$ & Evident restriction of motion \\
\hline & & c & Fixation of a globe or globes \\
\hline \multirow[t]{5}{*}{5} & $\mathrm{C}$ & & Corneal involvement \\
\hline & & 0 & absent \\
\hline & & a & Stippling of cornea \\
\hline & & $b$ & Ulceration \\
\hline & & c & Clouding, necrosis, perforation \\
\hline \multirow[t]{5}{*}{6} & $\mathrm{~S}$ & & Sight loss (visual acuity) \\
\hline & & 0 & $>0.67$ \\
\hline & & a & $0.67-0.33$ \\
\hline & & $b$ & $0.33-0.10$ \\
\hline & & $\mathrm{c}$ & $<0.10$ \\
\hline
\end{tabular}

ing, even passive smoking, represents a risk factor for more severe orbital involvement and higher activity score by the interaction with proinflammatory cytokines $[17,18]$.

Treatment of GO is focused mainly on equilibration of thyroid function and reduction of inflammation by local and systemic anti-inflammatory drugs according to guidelines set by EUGOGO [19].

\section{Subjects and methods}

In this study participated 25 patients with Graves' disease and Graves' orbitopathy, followed-up in the Endocrinology Clinic of Tîrgu Mureș. We investigated serum levels of interleukin-1 (IL-1), interleukin-2 (IL-2), interleukin-4 (IL-4), interleukin 6 (IL-6), interleukin-8 (IL-8), interleukin-10 (IL-10), monocyte chemoattractant protein-1 (MCP-1), tumor necrosis factor-alpha (TNF- $\alpha$ ) and interferon-gamma (IFN- $\gamma$ ), in order to examine the contribution of these cytokines in the immune response of the disease. Diagnosis of Graves disease was made upon clinical and biochemical-immunological criteria: goiter, signs of thyrotoxicosis (suppressed TSH with elevated FT4 and/or FT3) or treatment for the disease, antithyroid antibodies (TSH Receptor Antibodies-TRAb, antithyroid peroxidaseTPO), and ophthalmological exam for the presence of the orbitopathy.

The onset of Graves' disease and orbitopathy were noted, as the time elapsed between the thyroid symptoms and ophthalmic symptoms. Smoking status was recorded as
Table II. Clinical Activity Score. For each item present, 1 point is given. The sum of these points is the CAS.

\begin{tabular}{|c|c|c|}
\hline \multirow[t]{2}{*}{ Pain } & 1 & $\begin{array}{l}\text { Painful, oppressive feeling on or behind the globe, during } \\
\text { the last } 4 \text { weeks }\end{array}$ \\
\hline & 2 & $\begin{array}{l}\text { Pain on attempted up, side or down gaze, during the last } \\
4 \text { weeks }\end{array}$ \\
\hline \multirow[t]{2}{*}{ Redness } & 3 & Redness of the eyelids \\
\hline & 4 & $\begin{array}{l}\text { Diffuse redness of the conjunctiva, covering at least one } \\
\text { quadrant }\end{array}$ \\
\hline \multirow[t]{3}{*}{ Swelling } & 5 & Swelling of the eyelids \\
\hline & 6 & Chemosis \\
\hline & 7 & Swollen caruncle \\
\hline \multirow[t]{3}{*}{$\begin{array}{l}\text { Impaired } \\
\text { function }\end{array}$} & 8 & $\begin{array}{l}\text { Increase of proptosis of } \geq 2 \mathrm{~mm} \text { during a period of } 1-3 \\
\mathrm{~mm}\end{array}$ \\
\hline & 9 & $\begin{array}{l}\text { Decrease of eye movements in any direction } \geq 5^{\circ} \text { (de- } \\
\text { gree) during a period of } 1-3 \text { months }\end{array}$ \\
\hline & 10 & $\begin{array}{l}\text { Decrease of visual acuity of } \geq 1 \text { line(s) on the Snellen } \\
\text { chart (using a pinhole) during a period of } 1-3 \text { months }\end{array}$ \\
\hline
\end{tabular}

smoker (even patients who quit in time) and non-smoker (never smoked).

Serum cytokines (IL-1, IL-2, IL-4, IL-6, IL-8, IL-10, IFN- $\gamma$, TNF- $\alpha$ ) were measured by biochip-cytokine array (Randox Laboratories Ltd., UK) with patients' informed consent at the same time with routine blood tests on admission.

Statistical analysis was performed using JMP 7.0 (descriptive statistics, t-test, Chi-test, Kruskall-Wallis test), p $<0.05$ was considered statistically significant.

\section{Results}

Patient distribution: of the 25 patients 10 were male (40\%), 15 female $(60 \%)$, mean age 43.08 years $( \pm 2.16)$, the youngest patient was 24 , the oldest 58 . A number of 14 of patients were smokers ( 7 male and 7 female), 11 never smoked ( 3 male, 8 female).

Ophthalmopathy onset in relation to Graves' disease evolution: in 12 patients ophthalmological signs appeared simultaneously (within 1-2 months) with thyroid disease, in $13(52 \%)$ patients there was a known history of thyroid disease, before the orbitopathy appeared. In these, 5 patients developed ophthalmic disease within 12 months, another 6 within 12 to 36 months, and 2 after 3 years after the beginning of hyperthyroidism (Figure 1).

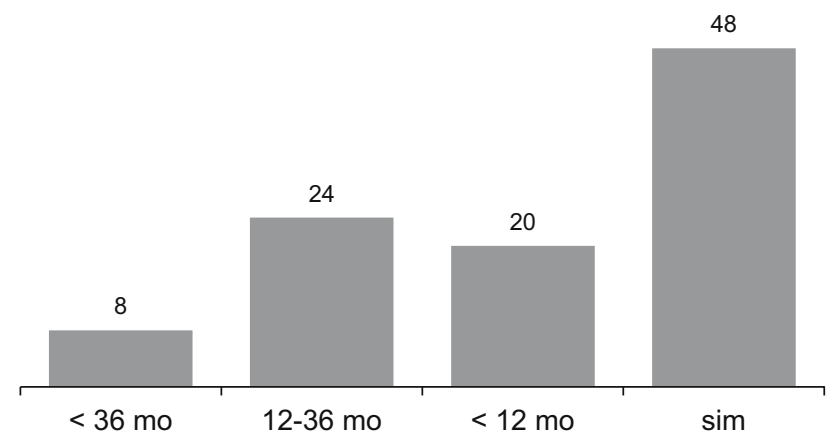

Fig. 1. Onset of Graves' orbithopathy in relation to onset of thyroid disease (numbers showing percentage of patients, $\mathrm{mo}=$ months, sim= simultaneously) 
Table III. Cytokine measurements in patients with Graves' orbitopathy according to smoking habit

\begin{tabular}{|c|c|c|c|c|c|c|c|}
\hline Cytokine & $\begin{array}{c}\text { Mean } \pm \mathrm{SD}(\mathrm{pg} / \mathrm{ml}) \\
\text { All patients } \\
\mathrm{n}=25\end{array}$ & $\mathrm{Cl}(95 \%)$ & $\begin{array}{c}\text { Mean } \pm \text { SD }(\mathrm{pg} / \mathrm{ml}) \\
\text { Smokers } \\
\mathrm{n}=14\end{array}$ & $\mathrm{Cl}(95 \%)$ & $\begin{array}{c}\text { Mean } \pm \text { SD }(\mathrm{pg} / \mathrm{ml}) \\
\text { Nonsmokers } \\
n=11\end{array}$ & $\mathrm{Cl}(95 \%)$ & $P$ value \\
\hline IL-1 & $0.95 \pm 0.08$ & $0.78-1.11$ & $0.86 \pm 0.10$ & $0.64-1.08$ & $1.05 \pm 0.12$ & $0.80-1.30$ & NS \\
\hline IL-2 & $6.71 \pm 0.61$ & $5.43-7.98$ & $6.44 \pm 0.83$ & $4.70-8.17$ & $7.05 \pm 0.94$ & $5.09-9.01$ & NS \\
\hline IL-4 & $3.98 \pm 0.29$ & $3.36-4.59$ & $4.15 \pm 0.40$ & $3.31-4.98$ & $3.76 \pm 0.45$ & $2.82-4.70$ & NS \\
\hline IL-6 & $4.0176 \pm 1.35$ & $1.21-6.82$ & $6.42 \pm 1.98$ & $2.32-10.52$ & $2.12 \pm 1.75$ & $-1.50-5.76$ & 0.047 \\
\hline IL-8 & $15.67 \pm 3.00$ & $9.47-21.87$ & $10.92 \pm 3.81$ & $3.02-18.82$ & $21.73 \pm 4.30$ & $12.81-30.64$ & 0.051 \\
\hline IL-10 & $2.10 \pm 0.20$ & $1.67-2.52$ & $2.23 \pm 0.27$ & $1.66-2.80$ & $1.92 \pm 0.31$ & $1.28-2.57$ & NS \\
\hline MCP-1 & $321.00 \pm 33.77$ & 251.30-390.70 & $287.62 \pm 44.89$ & $194.76-380.49$ & $363.48 \pm 50.64$ & $258.71-468.24$ & 0.046 \\
\hline $\mathrm{TNF} \alpha$ & $3.65 \pm 0.35$ & $2.91-4.38$ & $3.22 \pm 0.46$ & $2.25-4.18$ & $4.20 \pm 0.52$ & $3.11-5.28$ & 0.036 \\
\hline IFN $\gamma$ & $2.76 \pm 0.27$ & $2.19-3.32$ & $2.60 \pm 0.370$ & $1.84-3.37$ & $2.95 \pm 0.41$ & $2.08-3.81$ & NS \\
\hline
\end{tabular}

Staging the disease severity and activity according to guidelines of EUGOGO, available at http://eugogo.eu/ clinical_evaluation.php, our patients presented as follows: 17 patients were considered as having mild or moderate GO with NOSPECS < stage IIIb, of these 12 were stage II, and 5 patients had stage III ophthalmopathy; 8 patients had severe GO, defined as stages IIIc-V, only one patient having optic neuropathy, therefore recorded as stage $\mathrm{V}$. Clinically active disease was considered when clinical activ- ity score (CAS) exceeded 4 points, so 12 patients had inactive disease, and 13 patients had active GO ( six patients with CAS $=4$, five patients with CAS $=5$, and two patients with CAS = 6).

Mean cytokine level measurements are listed in Table III. We wanted to see if there's a difference in serum cytokine levels in smokers vs. non-smokers. After statistical analysis we found that smokers have higher IL-6 levels $(6.42 \pm 1.98$ $\mathrm{pmol} / \mathrm{l}$ vs. $2.12 \pm 1.75 \mathrm{pmol} / \mathrm{l}, \mathrm{p}<0.05)$, and lower MCP1
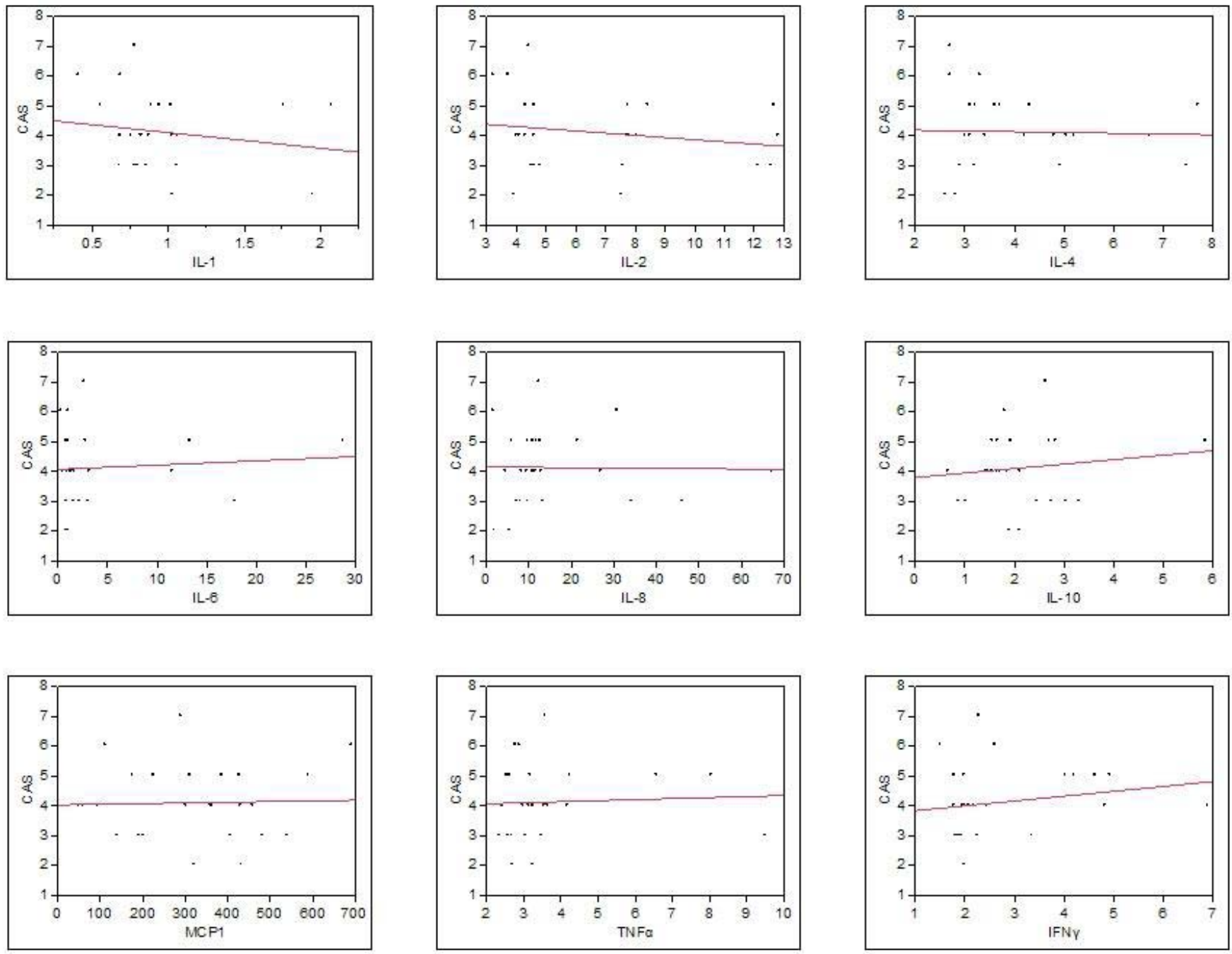

Fig. 2. Serum interleukin levels and Clinical Activity Score 
levels $(287.62 \pm 44.89 \mathrm{pmol} / \mathrm{l}$ vs. $363.48 \pm 50.64 \mathrm{pmol} / \mathrm{l}$, $\mathrm{p}<0.05)$, lower IL-8 levels $(10.92 \pm 3.81 \mathrm{pmol} / \mathrm{l}$ vs. 21.73 $\pm 4.30 \mathrm{pmol} / \mathrm{l}, \mathrm{p}<0.05)$ and TNF- $\alpha(3.22 \pm 0.46 \mathrm{pmol} / \mathrm{l}$ vs. $4.20 \pm 0.52 \mathrm{pmol} / \mathrm{l}, \mathrm{p}<0.05)$ levels compared to nonsmokers. No statistically relevant differences were found in IL-1, IL-2, IL-4, IL-10, IFN- $\gamma$ serum levels.

According to disease activity defined by CAS and cytokine profile, we found that there is a weak positive correlation between IL-10 $(\mathrm{r}=0.26, \mathrm{p}<0.05)$ and clinical activity score, IFN- $\gamma$ and clinical activity score $(r=0.23$, $\mathrm{p}<0.05)$, and a weak negative correlation between IL-1 and CAS $(\mathrm{r}=-0.24, \mathrm{p}<0.05)$ (Figure 2). For the rest of the studied parameters, we found no statistical correlation regarding disease activity and serum cytokine levels.

\section{Discussions}

In the present study we demonstrated differences in serum interleukin levels in patients with Graves' orbitopathy. Several studies tried to define the exact serum interleukin profile in attempt to predict progression and response to medical treatment. Some of these cytokines are involved in Th1 cell mediated immune reactions (IL-2, TNF- $\alpha$ and IFN- $\gamma$ ), while others are related to Th2 humoral responses (IL-4, IL-5, IL-10). Other cytokines are secreted by activated fibroblasts or macrophages (IL-1, IL-6, IL-8,IL-16, TGF- $\beta$, RANTES, PGE2) and they sustain chronic inflammation $[8,20]$. IL- 1, TNF- $\alpha$ and IFN- $\gamma$ are pro-inflammatory cytokines that increase adhesion molecule (ICAM-1), heat shock protein 72, HLA class II molecules' expression on orbital fibroblasts and stimulate adipocyte differentiation. The stimulated fibroblasts secrete small cytokines as MCP1 and IL-8, which participate in recruitment of monocytes, lymphocytes and neutrophils to the site of inflammation. In addition, studies have shown that IL-1 is responsible for the production of glycosaminoglycans. Blocking TNF- $\alpha$ or IL-1 production by specific monoclonal antibodies represents a promising therapeutic possibility for a subset of patients. Some studies show that there is an increased level of IL-10 in GO patients that respond to steroid treatment, and that the proportion of IL-10 vs. IL-4 (mainly an antiinflammatory cytokin) could be used for selecting patients before therapy. IL- 6 has been shown to stimulate the expression of TSH-receptor gene and is a negative predictive factor for response to treatment $[15,16,24]$. These results are controversial, mainly due to the small number of patients included in studies. In our study IL-6 levels proved to be more elevated in smoker patients when compared to non-smokers suggesting the proinflammatory potential of smoking on orbital fibroblasts by increasing HLA II molecule expression. This finding is important because smokers are at higher risk in developing GO, the response to medical treatment is poorer and progression is more severe in active smokers $[18,21,22,23]$. Therefore it is important for patients to understand that quitting can improve curing chances, and smoking being a modifiable risk factor they should be encouraged and helped to cease smoking.
The lower IL-8, MCP-1 and TNF- $\alpha$ levels found in smokers suggest that the inflammation is exacerbated in smokers and cytokines responsible for fibroblast activation and adipocyte differentiation could be slightly reduced. Considering that almost half of patients presented had recent-onset GO, we would have expected to have more evident Th1 pattern in cytokine profile, namely elevated IL-2, IFN- $\gamma$ and TNF- $\alpha$, described in other studies $[13,14]$. The small number of patients may be the cause of this bias.

Several studies suggested also that serum interleukin levels, and more evident retroorbital cytokine levels are strongly correlated with disease activity [20,24,25]. We found that only for IL-10 and IFN- $\gamma$ there is a slight increase with clinical activity score, and that IL-1 levels decreased with higher scores of disease activity. The discrepancy of cytokine profiles may reflect different patient characteristics, such as disease stage and disease activity.

\section{Conclusion}

Our work shows that there is a difference in serum IL-6 in smoking and non-smoking GO patients. We recommend stopping smoking for all patients with Graves disease and/ or Graves orbitopathy.

The activity of the disease characterized by the extension of inflammation and impairment of function correlated with increasing serum IL-10, IFN- $\gamma$ and lower IL-1 levels. The importance of these findings need to be assessed in larger patient populations.

As a conclusion, our study suggests that cytokines play a major role in sustaining and promoting inflammation in the retro orbital tissue of GO patients, and serologic profiling could help in choosing more aggressive treatment protocols in patients with active disease.

\section{References}

1. Marcocci C, Bartalena L, Bogazzi F, Panicucci M, Pinchera A. Studies on the occurrence of ophthalmopathy in Graves' disease. Acta Endocrinol (Copenh). 1989;120(4):473-8.

2. Bartley GB, Fatourechi V, Kadrmas EF, et al. Clinical features of Graves' ophthalmopathy in an incidence cohort. Am J Ophthalmol. 1996;121(3):284-90.

3. Mohaseb K, Linder M, Rootman J, et al. Development and validation of a patient symptom questionnaire to facilitate early diagnosis of thyroidassociated orbitopathy in graves' disease. Orbit. 2008;27(6):419-25.

4. Dickinson AJ, Perros P. Controversies in the clinical evaluation of active thyroid-associated orbitopathy: use of a detailed protocol with comparative photographs for objective assessment. Clin Endocrinol (Oxf). 2001;55(3):283-303.

5. Eckstein AK, Lösch C, Glowacka D, et al. Euthyroid and primarily hypothyroid patients develop milder and significantly more asymmetrical Graves ophthalmopathy. Br J Ophthalmol. 2009;93(8):1052-6.

6. 6.Cozma I, Cozma LS, Boyce RL - Variation in thyroid status in patients with Graves' orbitopathy. Acta Endo (Buc). 2009;5(2):191-198.

7. Mourits MP, Koornneef L, Wiersinga WM, et al. Clinical criteria for the assessment of disease activity in Graves' ophthalmopathy: a novel approach. Br J Ophthalmol. 1989;73(8):639-44.

8. Terwee CB, Prummel MF, Gerding MN, et al. Measuring disease activity to predict therapeutic outcome in Graves' ophthalmopathy. Clin Endocrinol (Oxf). 2005;62(2):145-55.

9. Prummel MF, Bakker A, Wiersinga WM, et al. Multi-center study on the characteristics and treatment strategies of patients with Graves' orbitopathy: the first European Group on Graves' Orbitopathy experience. Eur J Endocrinol. 2003;148(5):491-5. 
10. Dolman PJ. Evaluating Graves' orbitopathy. Best Pract Res Clin Endocrinol Metab. 2012;26(3):229-48.

11. Gerding MN, van der Meer JW, Broenink M, et al. Association of thyrotrophin receptor antibodies with the clinical features of Graves' ophthalmopathy. Clin Endocrinol (Oxf). 2000;52(3):267-71.

12. Eckstein AK, Johnson KT, Thanos M, Esser J, Ludgate M. Current insights into the pathogenesis of Graves' orbitopathy. Horm Metab Res. 2009;41(6):456-464.

13. Bellur SP, Bahn RS, Smith TJ. Current Perspective on the Pathogenesis of Graves' Disease and Ophthalmopathy. Endocrine Reviews. 2003;24(6):802-835

14. Pappa A, Lawson JMM, Calder V, et al. T cells and fibroblasts in affected extraocular muscles in early and late thyroid associated ophthalmopathy. Br J Ophthalmol. 2000;84:517-522.

15. Han R, Smith TJ. Induction by IL-1 1 of Tissue Inhibitor of Metalloproteinase-1 in Human Orbital Fibroblasts: Modulation of Gene Promoter Activity by IL-4 and IFN- $\gamma$. J. Immun. 2005;174(5):3072-3079.

16. Cawood TJ, Moriarty P, O'Farrelly P, O'Shea D. The effects of tumour necrosis factor- $\alpha$ and interleukin1 on an in vitro model of thyroidassociated ophthalmopathy; contrasting effects on adipogenesis. Eur J Endocrinol. 2006;155:395-403.

17. Krassas GE, Wiersinga W. Smoking and autoimmune thyroid disease: the plot thickens. Eur J Endocrinol. 2006;15:4777-78.
18. Cawood TJ, Moriarty P, O'Farrelly P, O'Shea P. Smoking and ThyroidAssociated Ophthalmopathy: A Novel Explanation of the Biological Link. J Clin Endocrinol Metab. 2007;92:159-64.

19. Bartalena L, Baldeschi L, Dickinson A, et al. Consensus statement of the European Group on Graves' orbitopathy (EUGOGO) on management of GO Eur J Endocrinol. 2008;15:8273-285.

20. Wakelkamp IMMJ, Bakker O, Baldeschi L, Wiersinga WM, Prummel MF. $\mathrm{TSH}-\mathrm{R}$ expression and cytokine profile in orbital tissue of active vs. inactive Graves' ophthalmopathy patients. Clin Endocrin. 2003;58(3):280-287.

21. Szucs-Farkas Zs, Toth J, Kollar J, et al. Volume Changes in Intra- and Extraorbital Compartments in Patients with Graves' Ophthalmopathy: Effect of Smoking. Thyroid. 2005;15(2):146-151.

22. ThorntonJ, Kelly SP, Harrison RA, Edwards R. Cigarette smoking and thyroid eye disease: a systematic review. Eye. 2007;21:1135-1145.

23. Wiersinga WM and Bartalena L. Epidemiology and Prevention of Graves' Ophthalmopathy. Thyroid. 2002;12(10):855-860.

24. de Carli M, D'Elios MM, Mariotti S, et al. Cytolytic T cells with Th1-like cytokine profile predominate in retroorbital lymphocytic infiltrates of Graves' ophthalmopathy. J Clin Endocrin Metab. 1999;77:51120-1124.

25. Gianoukakis AG, Khadavi N, Smith TJ. Cytokines, Graves' Disease, and Thyroid-Associated Ophthalmopathy. Thyroid. 2008;18(9):953-95. 